\title{
IMPROVING PUBLIC TRANSPORT PASSENGER EXPERIENCE AND OPERATIVE ITINERARY TRANSPORT MANAGEMENT IN MEGALOPOLIS AREAS
}

\author{
Efimov A.D. \\ Department "International Logistics Systems and \\ Complexes" \\ Platov South-Russian State Polytechnic University (NPI) \\ Novocherkassk, Russia \\ Karaeva M.R. \\ Department "International Logistics Systems and \\ Complexes" \\ Platov South-Russian State Polytechnic University (NPI) \\ Novocherkassk, Russia
}

\author{
Zhivotchenko V.S. \\ Development department \\ Sirius Navigator \\ Novocherkassk, Russia \\ support@sirius.su \\ Meremkulov A.K. \\ Directorate \\ Sirius Navigator \\ Novocherkassk, Russia \\ dir@sirius.su
}

\author{
Nefedov V.V. \\ Department "General Engineering disciplines" \\ Platov South-Russian State Polytechnic University (NPI) \\ Novocherkassk, Russia \\ nvvnpi@gmail.com
}

\begin{abstract}
The possibilities of operative management of passenger traffic with the aim of adherence to schedules and intervals represent a serious issue in planning of city passenger traffic. This is a topical issue for cities having a network of roads and streets featuring the so called deep-rooted traffic jams. In this case development of routes and bus traffic schedules should be performed with due regard to the possible deviations in rolling stock operation schedules. Therefore the development of methods of control of passenger traffic systems and the correspondent operative management is the key to preserve a proper quality of passenger services. The present paper contains theoretic underpinning and experimental validation of use of programalgorithm complex for technological and institutional management along with the scientific underpinning of the methodology for establishment of traffic control in the real-time mode. The featured program-algorithm complex allows not only a fixation of discrepancies in calculated and actual public traffic schedules, but also provides for operative corrections of the schedules of buses; if necessary, it also allows corrections of the number of actually launched rolling stock units on the line.
\end{abstract}

Moreover, the passengers waiting for their bus to arrive at halting point can monitor the correspondent rolling stock unit in every point of its route, thus leading to a possibility to plan a further way of the user. Increase in quality of passenger transport services for passengers as end users of the services is impossible without application of the modern information management systems.
Keywords- rolling stock, program-algorithm complex, public traffic, passenger traffic, schedules, operative management.

\section{INTRODUCTION}

Maintenance of high quality of public transport passenger services is a significant task for modern cities with population of more than one million people. Use of metro transport in combination with surface public transport is an obvious solution for this task. Still in certain cities such strategy could not be realized because of the issues combined with its economic feasibility.

Therefore the main expected characteristic of surface public transport is the type of its organization supporting achievement of the target goals of its operations. As of today, many passenger transportation companies use traffic control officers on the key halting points along the existing routes. Such traffic control staff maintains the log of intervals between the incoming and leaving rolling stock units in a real time mode and coordinates their idle periods during the dropon and drop-off of passengers.

This way of operative management of rolling stock on route is both contravening the rules of passenger transportation, established by the Charter of motor transport, and creating additional risks of traffic accidents, induced by 
the need of the line traffic control officers to enter the pavement part of halting points.

Additionally, the efficacy of operation of this system as a whole fully depends on the subjective opinion of the line traffic control officer, sending the rolling stock unit on its line and not taking into account the developed transport situation on the street and road network. Headway of public transport is often interrupted after two or three sections between halting stations are passed; this happens due to traffic jams, specifics of each driver's manner of driving and technical properties of rolling stock units.

Development of specialized models for city public transport is a complex process. The complexity results in the question of what will be the properties of operation mode of the model system in case when the main defining parameters attain defined values. Such descriptions in models are made at the production and technological level in aggregate units. Therefore it is necessary to develop models of a higher class not only describing the process of transportation but also separate stages of its organization and describing the causeeffect relation between the characteristics of the process and output parameters.

\section{THEORETICAL PART}

Strategies used for setting a determined task are more often realized in transport and logistics modeling and algorithmic computation, whereby solving of the derived model supposes use of classic algorithms in mathematical programming. Determined problems lead to vast investments in time, needed to set up the linear integral-valued programs that can be effectively solved. Nevertheless they fully ignore the factor of uncertainty and complex dynamics, which may occur under the real circumstances.

The most widespread approach to modeling of the problems of distribution of resources in practice is the posing of problem with a determined task combined with use of mathematical programming algorithms developed for this parameter.

The three main components comprise the basis of numerical methods applied for solving tasks in optimization of management as follows:

Methods for solving the differential equations and integration of functions;

Methods for solving the systems of nonlinear algebraic equations;

Methods for solving nonlinear optimization tasks.

As a rule, dynamic tasks of resources distribution lead to a very high dimension factor in stochastic dynamic programming. A set of approximation algorithms were successful in applications combined with transport and logistics [1-3].

Algorithms include several key ideas that are affected by the issue of dimensionality. Among these ideas is the reformulation of the dynamic programming around the recursion variable at the stage "after decision-making", modeling on the basis of methods of stochastic approximation and continuous approximation architectures from functional forms lightening the whole program solutions for optimization of solutions to subproblems.

This approach is properly working for tasks with thousands of discrete resources with tens of thousands of various attributes (Eminently, being the vector of state with tens of thousands sizes)

Additionally, the convergence rate of teaching the functional values of approximations seems to be sufficiently dynamic. This is important, because huge projects may demand one hour for single iteration.

As a rule, only one target function with an additional set of limitations is taken into consideration when solving tasks of discrete optimization. This approach does not allow taking into account the intercorrelation between participants in the system, which may lead to development of ineffective solutions [4-6].

Analysis of methods of solving tasks in the city public traffic management shows that the most promising methods are meta-heuristic ones, thus, for instance, genetic algorithms [7, 8]. The main characteristics of such algorithms are the possibilities during optimization to, firstly, use the target function and not its evaluations or equations and, secondly, to take into account the necessary amount of limitations. In its work such algorithm processes a multitude of alternative decisions establishing the search for promising variants of decisions with due regard for the selected functions and limitations.

Under these circumstances a special role is assigned to the development of an intellectual system for operative management of public transport units. Management algorithm based on the following main performance indicators has to be inherent in this system [9-11]:

- population of urban agglomeration;

- quantity of rolling stock per 1000 residents;

- route network density;

- transport network load;

- technical conditions of hardware and rolling stock;

- technical condition of hardware installed inside the vehicles;

- qualification of drivers;

- rolling stock passenger capacity;

- time of departure;

- time of arrival;

- idle time for each bus;

- time for passenger turnover on each halting point;

- distances between halting points;

- maximum transit time for each interval of the route; 
- minimum transit time for each interval of the route;

- place of the departure;

- quantity of passenger places at the departure;

- quantity of halting points on the route;

- quantity of intersections with railway roads;

- observance of rules for technical use of rolling stock;

- speed enforcement;

- observation of traffic schedules;

- halting points compliance;

- quantity of change points.

- tariff per passenger;

- fare per luggage unit;

- quantity of rolling stock units on the line;

- quantity of intersections;

- journey time;

- journey length (haul cycle);

- operating hours of the route;

- servicing hours during winter;

- quantity of changes during one trip;

- waiting time for the bus;

- drop-on zone;

- drop-off zone;

- comfort during the trip;

- information contents;

- waiting time for the bus;

- quantity of changes per one journey;

- level of accessibility of public transport;

- opportunity to transport luggage;

- stability of public transport;

- minimum quantity of changes;

- convenience at drop-on and drop-off;

- adherence to traffic schedule;

- adherence to traffic regulations;

- voice announcement of halting points;

- sufficient heating and ventilation;

- opportunities for transportation of luggage;

Taking into account all the enlisted factors, we suggest the standing according to which the management of passenger transportation services has to correspond to the demands of social nature, operational suitability, handling properties, safety and sustainability.
It has to be taken into account that the factors of efficacy from the view of stakeholders in the passenger transportation system are contradictory. For example, the cut-down on waiting time for passengers is obviously combined with an increase of the rolling stock quantity on the route and, correspondingly, with a decease in its load rate and commercial feasibility. Still, the intent of transport organizations to increase profit rate may lead to the population's rejection to use public transport, thus leading to emerging of competing city passenger transportation organizations [12].

Therefore the evaluation of factors of efficacy has to be performed with due regard for needs of all stakeholders in the city public transport system.

\section{RESULTS AND DISCUSSION OF THE RESULTS}

In light of the aforementioned we suggest methodology for operative management of route-based rolling stock on the basis of applied program-algorithm approach used for planning and performance of passenger transportation. This approach presumes establishment of technical systems monitoring the rolling stock in real time and providing for intercoordination of operations of each transport unit. Information from rolling stock arrives at a local server and, depending on the values of controlled parameters, a driver receives control orders on the working display. The local server manages the algorithm including input values of management parameters as it is presented in fig. 2 .

As it can be seen in fig. 2, the use of the algorithm allows one traffic control officer to control operations of the whole set of rolling stock and directly affect the operating and halt conditions of rolling stock. The principle for setting up of the algorithm is based on control of correspondence between the time of journey and the schedule of buses with speed coordination of the rolling stock units that are following the "leader" to preserve the intervals between rolling stock units on the line.

Additionally the passengers waiting for public transport vehicles on halting points can use their mobile devices to see the location of the nearest bus and its estimated time of arrival and assess quality of rendering transport services.

Methodology for operative management and assessment of influence of quality of transport services takes into account the multiple facets of intercommunication among all factors relating to security of efficacy of functioning of the process of public transport services in megalopolis agglomerations.

The suggested algorithm for management of route-bound passenger rolling stock are used for perfection of rolling stock performance at OJSC ATP-3 "Transservice". The schedule for fixation of bus advancement relating to the planned schedule is presented in fig. 1 .

As we can see from figure 1, the traffic controlling officer can not only control the traffic regime of the rolling stock in a real time mode, but also detect the so called "red points" of the route. These are the places where traffic jams systematically or occasionally arise because of the existing traffic situation. 
Correspondently, this information can be integrated into the common system of intellectual management of transport flows in megalopolis and reorientation of its certain parts into the less loaded sectors of the street and road network. These actions will lead to a significant cut down on the travel time of public transport in the given loaded sections of the route network.

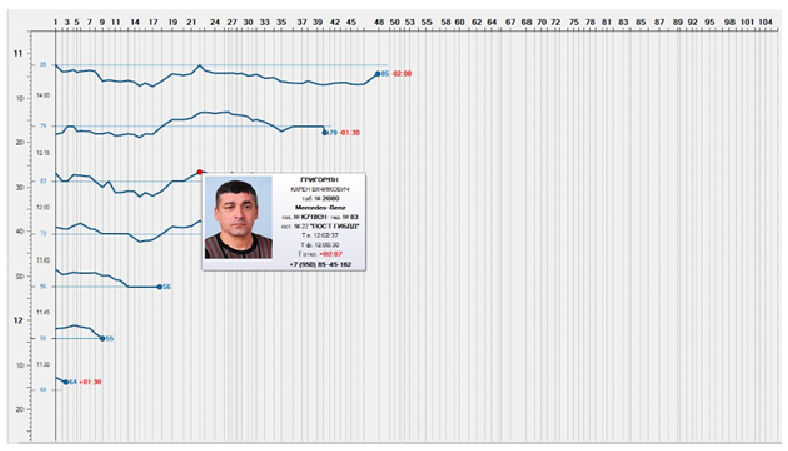

a)

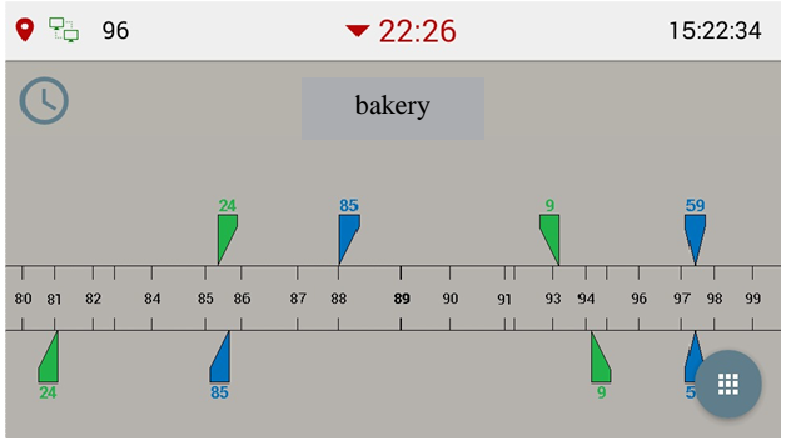

b)

Fig. 1. Application of the algorithm for public passenger transport services management

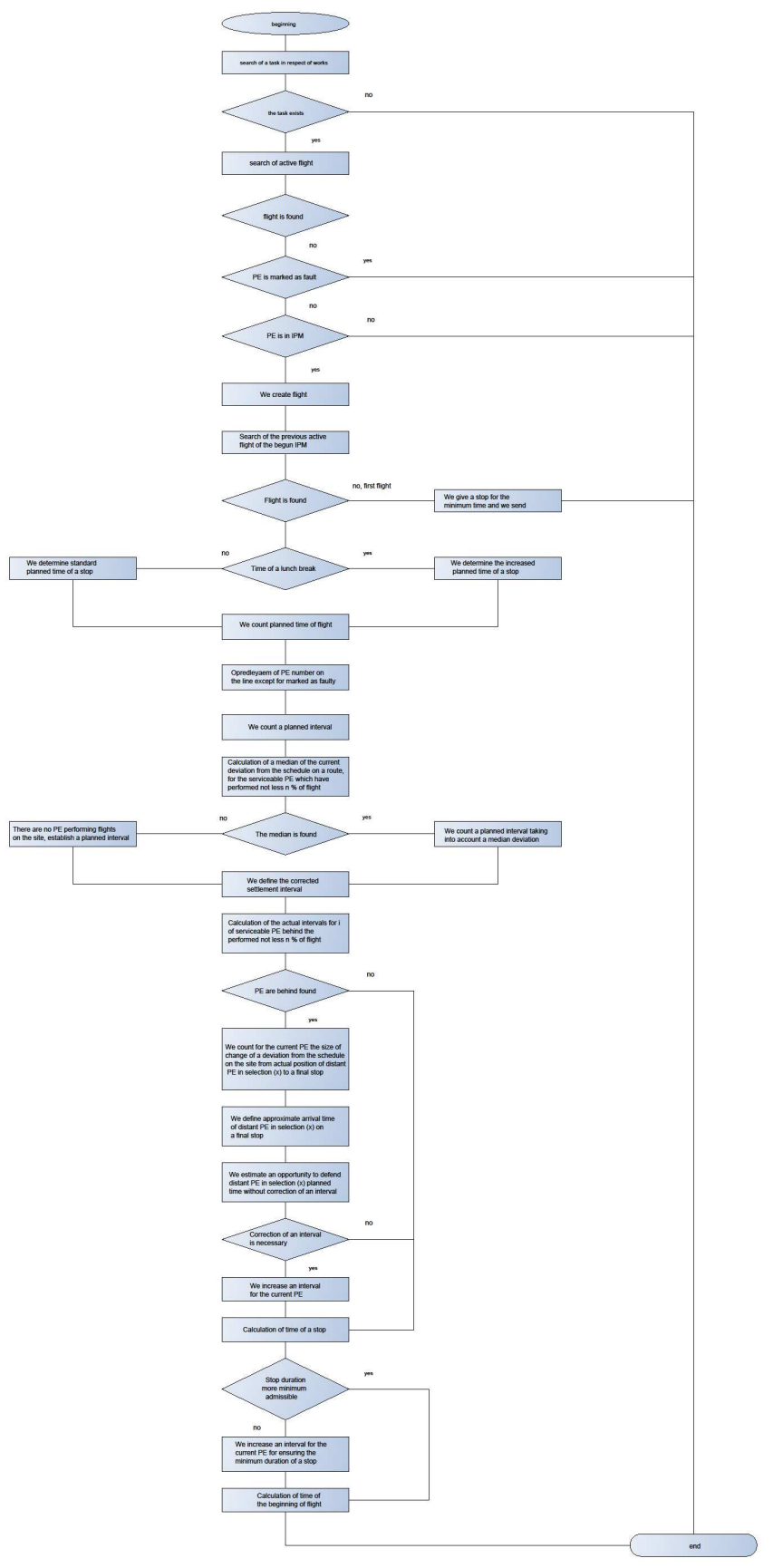

Fig. 2. Algorithm of operative management of route-bound public transport

\section{CONCLUSION}

The suggested methodology for program-algorithm management of the rolling stock on the regular urban routes is, firstly, oriented to the quality increase of passenger services and efficacy of operations of transport enterprises.

Realization of this program-algorithm complex makes it possible:

- Defining the release of proper quantity of the rolling stock on the line every 24 hours. 
- Defining the optimal quantity of the rolling stock on the line during peak traffic periods.

- $\quad$ Setting up the optimal schedule for each bus every 24 hours.

- Defining the current traffic situation.

- Correcting the schedule for buses in real time depending on the current traffic situation.

- Defining and correcting of speed for each bus depending on the current traffic situation.

- Defining the reasons for failures in the public transport schedule.

\section{References}

[1] M.R. Karaeva, N.V. Naphonenko "Optimizaciya organizacii i upravleniya sistemoj passazhirskih perevozok transportnym predpriyatiem.," Vestn. YURGTU (NPI). Ser. Soc.-ehkon. Nauki, Vol. 2, pp. 29-31, 2015.

[2] M.R. Karaeva "Primenenie matematicheskogo instrumentariya dlya resheniya zadach organizacii i upravleniya gorodskimi passazhirskimi perevozkami," Vestnik Rostovskogo gosudarstvennogo ehkonomicheskogo universiteta (RINH), № 1 (49), pp. 31-36, 2015.

[3] V.V. Zyryanov, V.G.Kocherga "Informacionnoe obespechenie zadach transportnoj logistiki," Logistika: Strategiya i taktika antikrizisnogo upravleniya: materialy Mezhdunar.nauch, prakt. konf. Rostov n/D., RGSU, 1999.
[4] V.A. Gudkov, L. B. Mirotin, Tekhnologiya, organizaciya i upravlenie passazhirskimi avtomobil'nymi perevozkami: ucheb.dlya vuzov, M.: Transport, 1997, $254 \mathrm{p}$.

[5] V.V. Kurejchik, V.M. Kurejchik "Ob upravlenii na osnove geneticheskogo poiska," Avtomatika i telemekhanika, Vol. 10, 2001.

[6] L.B. Mirotin "Novye logisticheskie podhody k formirovaniyu i funkcionirovaniyu transportnyh sistem Rossii," Avtotransportnyj kompleks: problemy i perspektivy razvitiya: materialy Mezhdunar. nauch.-prakt. Konf, M.: MADI, 2000.

[7] V.N. Parahina, V.N.Parahina, Formirovanie polistrukturnyh social'noehkonomicheskih sistem i osobennosti upravleniya imi :monografiya, M.: Neft' i gaz, 2007.

[8] YU.A. Stavnichij, Transportnye sistemy gorodov, M.: Strojizdat, 1990, $224 \mathrm{p}$.

[9] G.V. Bojko, Metodika optimizacii struktury transporta dlya obsluzhivaniya gorodskih passazhirskih perevozok, Volgograd: VGTU, 2006, $162 \mathrm{p}$.

[10] S.I. Matorin, O.A. Zimovec, A.G. ZHiharev "Tekhnologiya informacionnogo obespecheniya upravleniya na osnove sistemnogo podhoda «Uzel-Funkciya-Ob"ekt»," Vestnik Nacional'nogo tekhnicheskogo universiteta «Har'kovskij politekhnicheskij institut». Sbornik nauchnyh trudov, Tematicheskij vypusk: Informatika i modnlirovanie, Vol. 39, pp. 106-118, 2007.

[11] M. B. Petrov, M. A. ZHuravskaya, M. A. Levchenko, "Puti i vozmozhnosti formirovaniya druzhestvennoj seti regional'nogo i gorodskogo obshchestvennogo transporta pri sozdanii VSM," Innovacionnyj transport, Vol. 4 (22), pp. 3-8, 2016.

[12] V. M. Samujlov, E. V. Koshkarov, V. E. Koshkarov, M. A. Levchenko, Razvitie teorii i praktiki innovacionnoj deyatel'nosti na transporte i v dorozhnom hozyajstve, Ekaterinburg: UrGUPS, 2017. 